\title{
STUDI KUAT TEKAN BETON RECYCLE AGREGAT TERHADAP LINGKUNGAN AIR LAUT
}

\author{
Lusman Sulaiman'), Rinto Suppa ${ }^{2)}$ \\ 1) Dosen Program Studi Teknik Sipil, Universitas Andi Djemma, Palopo \\ ${ }^{2)}$ Dosen Program Studi Teknik Informatika, Universitas Andi Djemma, Palopo \\ ${ }^{1)}$ sulaimanlusman@gmail.com \\ ${ }^{2)}$ rintosuppa@gmail.com
}

\begin{abstract}
Abstrak
Tujuan penelitian ini adalah untuk menginvestigasi kekuatan tekan beton agregat recycle (BAR) terhadap pengaruh rendaman air laut. Total tiga puluh benda uji beton berbentuk silinder dengan ukuran $(\phi 150 \times 300 \mathrm{~mm})$ diproduksi dari dua jenis campuran yang berbeda. Jenis pertama beton agregat normal (BAN) adalah beton normal terdiri atas campuran semen portland, normal agregat kasar (NAK), pasir sungai dan air tawar. Adapun jens kedua (BAR) adalah beton recycle aggregate yang terdiri dari campuran semen Portland, recycle agregat kasar (RAK), pasir sungai dan air tawar. Adapun rencana target kuat tekan beton benda uji adalah sebesar $250 \mathrm{~kg} / \mathrm{cm}^{2}$ dengan nilai faktor air semen (fas) sebesar 0.45. Benda uji yang telah dibentuk kemudian dilakukan proses perendaman air laut secara langsung mulai umur $3,7,14,21$, dan 28 hari. Tiba saat waktu pengujian, benda uji dikeluarkan dari tempat perawatan dan selanjutnya diangin-anginkan untuk beberapa saat hingga material mengalami kering permukaan. Selanjutnya, pengujian kuat tekan dilakukan dengan menggunakan mesin kompresi tes sesuai prosedur SNI 1947:2011. Hasil pengujian memperlihatkan bahwa Pengaruh rendaman air laut tidak signifikan menurunkan kuat tekan beton BAR setelah membandingkan nilai kuat tekan beton BAN yang melampaui rencana mutu beton.
\end{abstract}

Kata Kunci: recycle agregat kasar, beton recycle, kuat tekan, air laut

\section{PENDAHULUAN}

Penggunaan agregat recycle beton telah menjadi alternative pengganti agregat alami untuk dijadikan material dalam pembuatan struktur beton dimana selain dapat mengefisiensikan biaya juga dapat mengurangi polusi udara (H. Guo et al.2018). Hal ini menjadikan beton recycle agregat (BRA) pilihan menjanjikan dalam pembangunan infrastruktur berkelanjutan pada saat sekarang ini. Selain itu, material agregat recycle (AR) dari sisa penghancuran dan buangan $(\mathrm{P} \& \mathrm{~B})$ konstruksi dan industri beton merupakan material yang cukup baik sebagai material konstruksi bangunan sebab telah banyak diteliti dan dikembangkan baik ditinjau dari sisi durabilitas maupun kekuatan.

Perkembangan bangunan infrastruktur yang mengarah ke daerah-daerah pantai sangat krusial terhadap ketahanan akibat serangan air laut baik secara langsung maupun tak langsung terkena air laut. Faktor konstituen air laut, seperti ion-ion klorida dan natrium, menjadikan kekuatan struktur beton tereduksi hingga mengakibatkan kegagalan atau keruntuhan pada struktur (Akshat Dimri, Jay Kr. Varshney, V. K. Verma, Sandeep Gupta, and G.B.Pant. 2015). Oleh karena itu, diperlukan studi lebih lanjut berkaitan dengan kemampuan suatu material struktur beton yang dapat bertahan dengan kondisi air laut hingga akhir masa layanannya. Ditambah BAR memiliki kualitas hampir serupa dengan beton agregat normal (BAN) dari sisi kuat tekan dan kesamaan dari sisi sifat fisik dan mekanik agregat.

Beberapa literatur telah mengemukakan bahwa BAR dapat digunakan sebagai pengganti BAN untuk konstruksi material struktural. Penelitian yang dilakukan oleh Malesev dkk memperlihatkan bahwa BAR memiliki performa cukup baik, yang tidak 
berbeda dengan BAN. Hal ini dilihat dari perilaku kedua material (BAR \& BAN) dari segi workability dan kuat tekan menunjukkan tidak ada perbedaan yang signifikan. Lebih lanjut, Studi yang dilakukan oleh Zaidi mengenai penilaian BAR bahwa penggunaan ukuran butiran 10 dan $14 \mathrm{~mm}$ RAK memiliki performa serupa dengan NAK dengan ukuran butiran yang sama.

Kekuatan tinggi dan durabilitas beton saat berada pada kondisi lingkungan air laut sangat diperlukan. Pengaruh air laut dipercaya memiliki kemampuan untuk dapat merusak struktur beton dan menjadi permasalahan utama yang dihadapi. Namun, Akhir-akhir ini dalam pembuatan beton air laut dijadikan media perawatan dan pencampuran dalam pembuatan beton (T. I. Abdel-Magid, O. M. Osman, O. H. Ibrahim, R. T. Mohammed, S. O. Hassan.2016).

and A. A. H. Bakkab,. Menurut peneliti Yue dkk mengungkapkan bahwa penurunan sifat mekanik BAR bukan karena perendaman air laut, akan tetapi sifat serap air RAK yang cukup tinggi. Seperti diketahui bahwa RAK memiliki mortar lama yang masih melekat sehingga dimungkinkan dapat menyerap air lebih banyak dibandingkan NAK (N. N. Kencanawati, J. Fajrin, B. Anshari, Akmaluddin, and M. Shigeishi.2015).

Dari penjelasan diatas, tujuan penelitian ini adalah untuk mengkaji dan mengevaluasi kekuatan tekan material BAR yang mengalami kondisi perendaman air laut secara langsung mulai dari umur beton 3, 7, 14, 21 dan 28 hari dengan nilai fas sebesar 0.45 . Adapun target kekuatan beton adalah sebesar $250 \mathrm{~kg} / \mathrm{cm}^{2}$ pada umur maksimum 28 hari. Kemudian hasil pengujian terhadap kuat tekan BAR dibandingkan dengan BAN sebagai pengontrol pengujian benda uji.

\section{METODOLOGI PENELITIAN}

\section{Semen}

Jenis semen yang digunakan dalam penelitian ini adalah tipe I-ASTM atau dikenal dengan ordinary portland cement (OPC) yang komposisi kimia dan sifat fisiknya dapat dilihat pada Tabel 1. Umumnya tipe semen ini digunakan dalam berbagai jenis infrastruktur dan bangunan perumahan. Sehingga cukup mudah didapat pada di pasaran dengan harga reltif terjangkau.

Tabel 1. Komposisi kimia dan fisik semen OPC

\section{Komposisi kimia dan fisik Konten}

\begin{tabular}{lc}
\hline $\mathrm{C}_{3} \mathrm{~S}(\%)$ & 50 \\
$\mathrm{C}_{2} \mathrm{~S}(\%)$ & 25 \\
$\mathrm{C}_{3} \mathrm{~A}(\%)$ & 12 \\
$\mathrm{C}_{4} \mathrm{AF}(\%)$ & 8 \\
$\mathrm{CSH}_{2}(\%)$ & 8 \\
$\mathrm{Kehalusan}_{\left(\mathrm{m}^{2} / \mathrm{kg}\right)}$ & 350 \\
Kuat Tekan $(1$ hari, MPa) & 7 \\
Panas hidrasi $(7$ hari, J/g) & 330 \\
\hline
\end{tabular}

Agregat

Agregat adalah bagian terpenting dari campuran dalam pembuatan beton. Pada penelitian ini, dua jenis agregat yang akan digunakan yaitu agregat halus dan kasar. 
Agregat halus menggunakan pasir sungai yang memiliki gradasi butiran maksimum $4.75 \mathrm{~mm}$ dan gradasi recycle agregat kasar maksimum $25 \mathrm{~mm}$. Agregat recycle diperoleh dengan menghancurkan sisa-sisa sampel beton hasil pengujian kuat tekan di laboratorium dari berbagai proyek lokal. Kemudian pemisahan antara mortar dan agregat kasarnya dilakukan hingga penyaringan dan penyortiran untuk mendapatkan ukuran yang diinginkan. Sebelum dilakukan desain campuran, analisis karakteristik fisik dan mekanik terhadap kedua agregat dapat dilihat pada Tabel 2.

Tabel 2. Karakter fisik dan mekanik agregat

\section{Karakteristik fisik dan} mekanik agregat

\section{Agregat recycle Pasir sungai}

\begin{tabular}{lcc}
\hline Berat jenis spesifik (kering oven) & 2.55 & 2.60 \\
Berat jenis spesifik (SSD) & 2.66 & 2.66 \\
Berat jenis spesifik (apparent) & 2.49 & 2.78 \\
Persen penyerapan (\%) & 2.49 & 1.63 \\
Persen keausan (\%) & 23.66 & - \\
Modulus kekasaran (\%) & 3.71 & 2.86 \\
\hline
\end{tabular}

\section{Air Pencampuran dan Perawatan}

Dua jenis air yang digunakan pada penelitian ini yaitu air tawar (AT) sebagai air pencampuran dalam pembuatan benda uji dan air laut (AL) sebagai media perawatan terhadap keseluruhan benda uji. Pada kedua proses ini, air yang digunakan sudah memenuhi standar air untuk pencampuran beton dan perawatan benda uji. Perawatan benda uji dengan menggunakan AL dilakukan secara langsung pada daerah laut selama proses perawatan benda uji.

\section{Desain dan Pengujian Benda Uji}

\section{a) Desain Campuran Benda Uji}

Proses desain campuran dalam pembuatan benda uji mengacu pada metode DOE dan kondisi di lapangan. Material yang digunakan dalam perencanaan desain campuran BAR adalah berdasarkan sifat-sifat hasil pengujian yang telah dilakukan. Ukuran benda uji kemudian dibentuk dari beton segor dengan ukuran silinder $\phi 150 \mathrm{x}$ $300 \mathrm{~mm}$ dan faktor air semen rencana sebesar 0.45. Target rencana kuat tekan pada umur perawatan 28 hari adalah sebesar $250 \mathrm{~kg} / \mathrm{cm}^{2}$ serta nilai slump beton segar \pm 120 $\mathrm{mm}$.

Dua kategori spesimen beton disiapkan dengan menggunakan $100 \%$ agregat recycle kasar yaitu pertama: semen, pasir, agregat recycle kasar dan air tawar (BAR), kedua: semen, pasir, agregat normal kasar dan air tawar (BAN) sebagai kontrol dan pembanding. Tabel 3 memperlihatkan proporsi campuran untuk setiap satu benda uji silinder dalam pembuatan BAR dan BAN. Material campuran dalam pembuatan beton yang telah terbentuk menghasilkan beton segar dan dicetak pada mold silinder hingga mengalami pengerasan. Benda uji kemudian dikeluarkan dalam cetakan dan ditempatkan pada ruangan terbuka hingga siap untuk dilakukan pengujian.

Tabel 3. Komposisi desain campuran beton

\begin{tabular}{ccccc}
\hline $\begin{array}{c}\text { Jenis } \\
\text { cetakan }\end{array}$ & Semen $(\mathbf{k g})$ & Pasir $(\mathbf{k g})$ & $\begin{array}{c}\text { Agregat recycle } \\
\text { kasar }(\mathbf{k g})\end{array}$ & Air $(\mathbf{k g})$ \\
\hline Silinder & 5.45 & 7.75 & 14.82 & 2.45 \\
\hline
\end{tabular}


Perlakuan yang diberikan dari total 30 benda uji selama masa perawatan tidak lepas dari prosesnya sesuai dengan yang ada di lapangan. Detail benda uji dapat diperlihatkan pada Tabel 4.

Tabel 4. Detail program pengujian laboratorium

\begin{tabular}{|c|c|c|c|c|c|c|}
\hline $\begin{array}{l}\text { Kategori } \\
\text { spesimen }\end{array}$ & Material penyusun & $\begin{array}{c}\text { Kuat tekan } \\
\text { rencana }\left(\mathrm{kg} / \mathrm{m}^{2}\right)\end{array}$ & Rasio w/c & $\begin{array}{c}\text { Spesimen } \\
\text { (buah) }\end{array}$ & $\begin{array}{c}\text { Waktu } \\
\text { perendaman (hari) }\end{array}$ & $\begin{array}{c}\text { Media } \\
\text { perendaman }\end{array}$ \\
\hline \multirow{5}{*}{ BAR } & Semen type I & \multirow{10}{*}{250} & \multirow{10}{*}{0.45} & 3 & 3 & \multirow{10}{*}{ Air laut } \\
\hline & Pasir sungai & & & 3 & 7 & \\
\hline & Agregat recycle kasar & & & 3 & 14 & \\
\hline & 1. & & & 3 & 21 & \\
\hline & Air tawar & & & 3 & 28 & \\
\hline & Semen type I & & & 3 & 3 & \\
\hline & Pasir sungai & & & 3 & 7 & \\
\hline BAN & Agregat normal kasar & & & 3 & 14 & \\
\hline \multirow{2}{*}{\multicolumn{2}{|c|}{ Air tawar }} & & & 3 & 21 & \\
\hline & & & & 3 & 28 & \\
\hline
\end{tabular}

b) Rancangan Pengujian

Pengujian kuat tekan (f'c) benda uji silinder beton dilakukan dengan menggunakan alat compression test atau alat uji kuat tekan dan detail spesimen uji seperti terlihat pada Gambar 5. Kapasitas alat yang akan digunakan pada penelitian ini dapat mencapai beban tekan hingga $50 \mathrm{MPa}$ dan kecepatan secara berkesinambungan rata-rata sebesar $0.14-0.34 \mathrm{MPa}$ /detik. Setiap hasil pengujian, tiga spesimen diuji untuk mendapatkan suatu nilai rata-rata. Keseluruhan prosedur pengujian mengacu pada SNI 1947:2011.

Besarnya kuat tekan $(\sigma)$ yang terjadi pada setiap spesimen uji, maka digunakan persamaan matematis dimana nilai kuat tekan berbanding dengan beban (P) dibagi luas penampang (A) seperti pada pers. 1.

$\sigma=\frac{P}{A}$

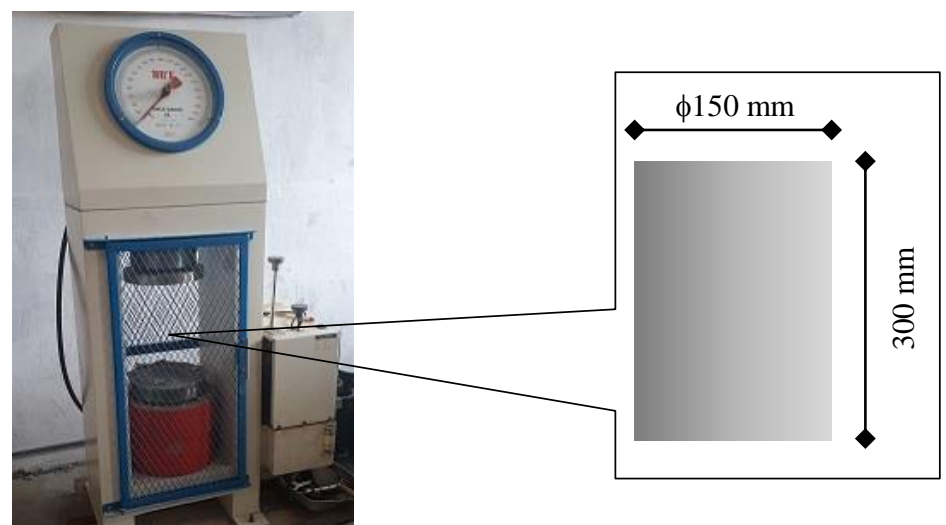

Gambar 1. Mesin kuat tekan dan spesimen 


\section{HASIL DAN PEMBAHASAN}

\section{Kuat tekan BAR dan BAN}

Hasil perbandingan uji kuat tekan 30 sampel silinder beton yang terdiri dari 15 BAR dan 15 BAN dapat diperlihatkan pada Gambar 2. Hasil pengujian ini diperoleh dari nilai rata-rata dari tiga buah benda uji untuk tiap waktu pengujian dengan target kuat tekan sebesar $250 \mathrm{~kg} / \mathrm{cm}^{2}$. Hubungan antara kuat tekan dan lama waktu perawatan jelas memperlihatkan bahwa seiring bertambahnya waktu perawatan maka peningkatan kuat tekan semakin besar hingga maksimum pada umur beton 28 hari untuk kedua jenis campuran. Tiap-tiap waktu pengujian 3, 7, 14, 21 dan 28 hari memaparkan bahwa kuat tekan BAN berada pada posisi lebih besar jika dibandingkan kuat tekan BAR.

Gambar 3 memperlihatkan nilai korelasi antara kuat tekan BAR dan BAN serta persamaan linear keduanya. Nilai $\mathrm{R}^{2}$ sebesar 0.9934 dari skala maksimum 1 menunjukkan korelasi tinggi. Selain itu persamaan linear pada pers. 2 dimana $R(N)$ adalah nilai kuat tekan BAR dan $\mathrm{N}$ adalah nilai kuat tekan BAN serta nilai Konstant $(\mathrm{K})=30.283$. Dengan adanya persaman linear ini, prediksi dapat dilakukan terhadap besar nilai kekuatan tekan BAR.

$$
R(N)=0.7909 N+K
$$

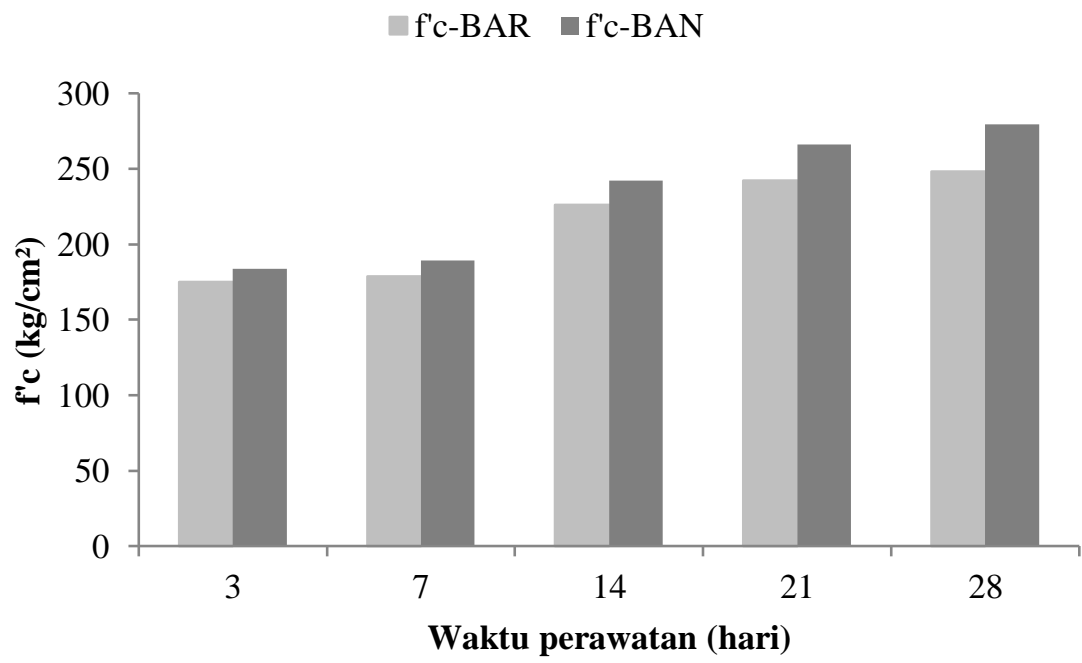

Gambar 2. Hasil pengujian kuat tekan BAR dan BAN

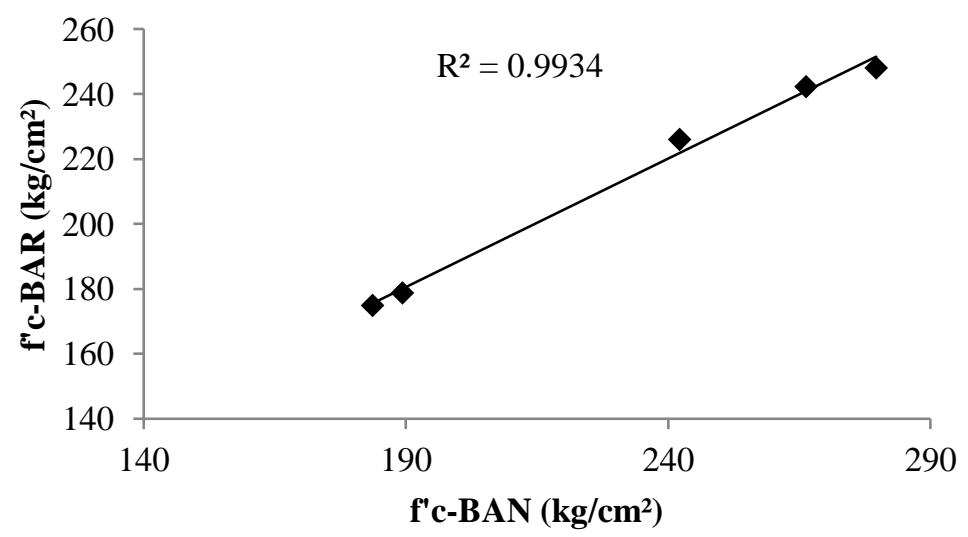

Gambar 3. Korelasi antara kuat tekan BAR dan BAN 


\section{Persen perubahan kuat tekan terhadap waktu perawatan}

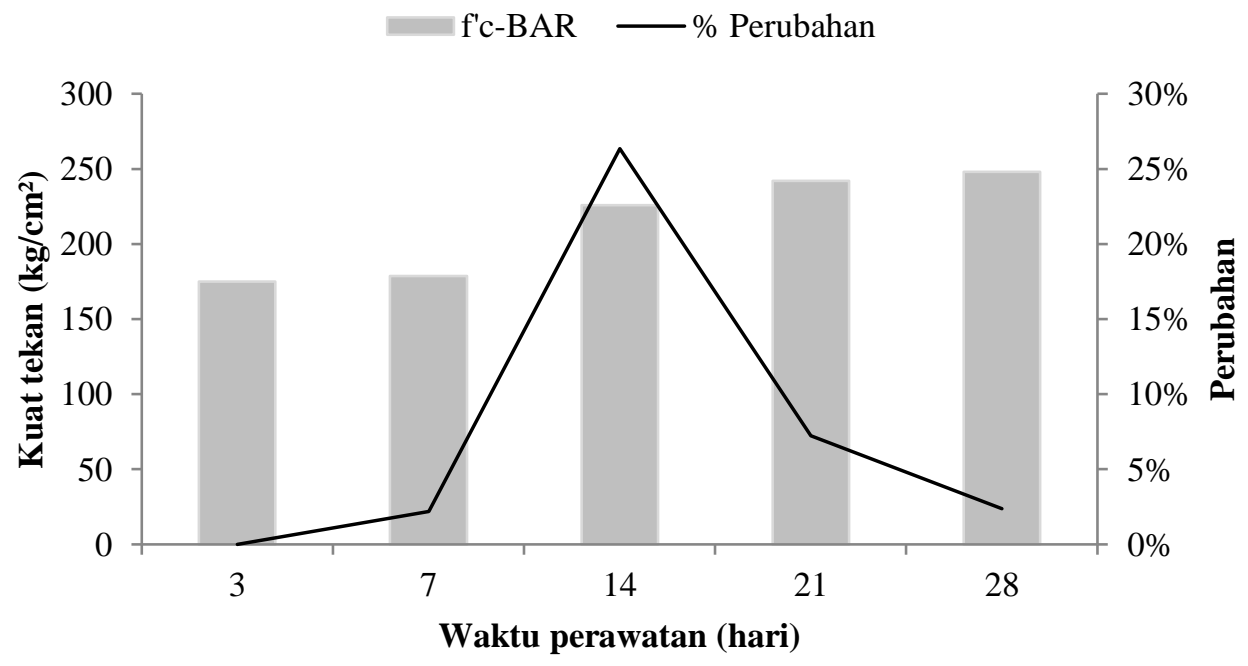

Gambar 4. Perubahan kuat tekan BAR terhadap waktu rendaman air laut

Gambar 4 memperlihatkan hasil pengujian kuat tekan BAR dengan variasi umur 7, 14, 21 dan 28 hari perawatan air laut dan persen perubahan kekuatan untuk tiap waktu perendaman. Awal pengujian kuat tekan 3 hari, nilai pengujian kuat tekan sebesar $174.91 \mathrm{~kg} / \mathrm{cm}^{2}$. kemudian saat mencapai 7 hari perawatan, nilai kuat tekan mengalami peningkatan sekitar $2.2 \%$ dan selanjutnya menigkat signifikan hingga $26.3 \%$ atau $225.84 \mathrm{~kg} / \mathrm{cm}^{2}$ pada umur 14 hari. Umur 21 dan 28 hari perawatan, kuat tekan berturut-turut mencapai 242.18 dan $247.94 \mathrm{~kg} / \mathrm{cm}^{2}$ atau meningkat sebesar 7.2 dan 2.4 persen. Nilai kuat tekan maksimal yang tercapai pada umur 28 hari terlihat belum mencapai target rencana , akan tetapi hasilnya tidak cukup jauh berbeda.

Gambar 5 menunjukkan hasil dan persen perubahan uji kuat tekan BAN sebagai kontrol beton yang mana proses produksi hingga perawatan air laut adalah sama. Garfik perubahan kekuatan tekan terlihat tidak jauh berbeda dengan hasil uji BAR, begitu juga halnya dengan nilai kekuatan uji tekan. Dari target yang direncanakan sebesar $250 \mathrm{~kg} / \mathrm{cm}^{2}$, kuat tekan BAN mencapai maksimum pada umur 28 hari sekitar $279.66 \mathrm{~kg} / \mathrm{cm}^{2}$ dimana nilai ini telah melampaui target yang direncanakan.

Berdasarkan hasil yang didapatkan dari pengujian eksperimen laboratorium, pengaruh perendaman air laut tidak signifikan mempengaruhi penurunan kekuatan beton dari segi kuat tekan. Walaupun target rencana kuat tekan belum tercapai, hal ini diyakini karena kualitas RAK yang belum maksimal dimana masih adanya mortar lama dan interaksinya dengan mortar baru yang masih lemah. 


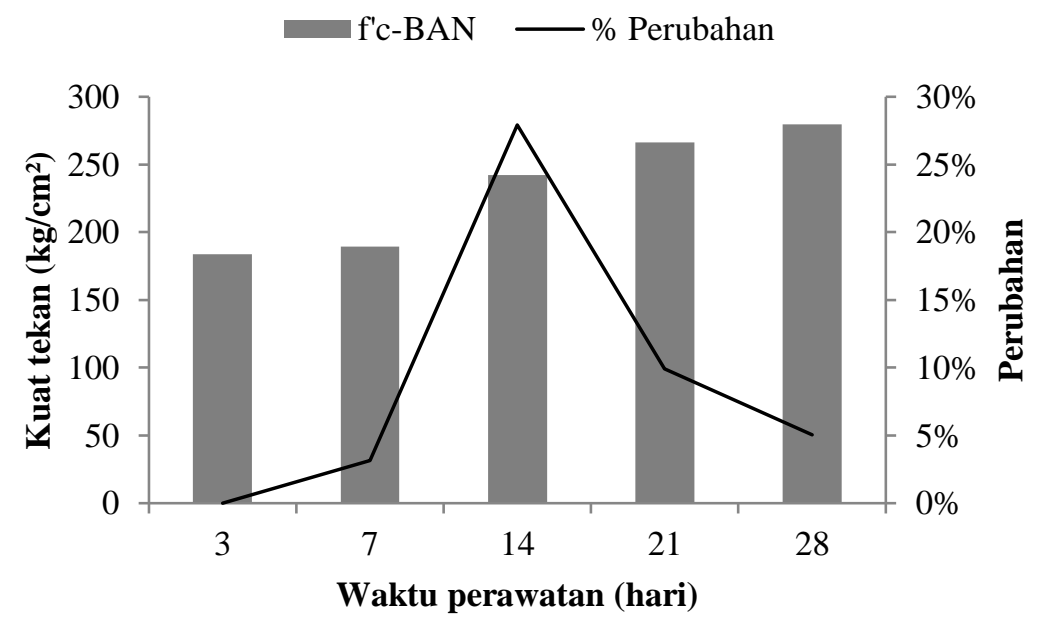

Gambar 5. Perubahan kuat tekan BAN terhadap waktu rendaman air laut

\section{Hubungan antara Berat sampel terhadap kuat tekan dan waktu perawatan}

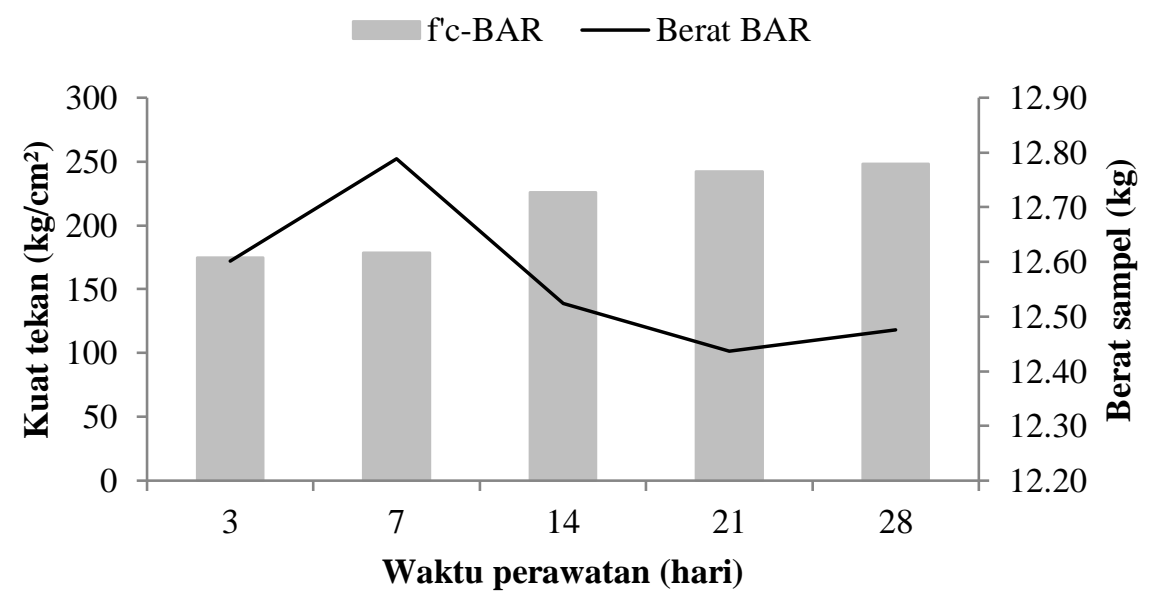

Gambar 6. Hubungan berat spesimen dan waktu rendaman terhadap kuat tekan BAR

Berat beton akan berengaruh pada penambahan beban yang akan dipikul oleh struktur. Sehingga sangat dimungkinkan untuk memiliki berat beton normal dimana secara umum digunakan dalam konstruksi bangunan. Gambar 6 memperlihatkan hubungan berat benda uji silinder dan durasi perendaman air laut serta besarnya kuat tekan BAR. Saat perendaman 3 hari berat benda uji sebesar $12.62 \mathrm{~kg}$, kemudian mengalami peningkatan sekitar $0.10 \mathrm{~kg}$ di umur 7 hari. selanjutnya berat benda uji mengalami penurunan fluktuatif hingga umur maksimum perawatan air laut 28 hari sebesar $12.47 \mathrm{~kg}$. Jika dikomparasikan dengan berat beton BAN maka nilai yang diperoleh tidak jauh berbeda dari beton BAR seperti pada Gambar 7 dimana beratnya diperoleh sebesar $12.37 \mathrm{~kg}$.

Selain itu, berdasarkan perolehan berat tiap waktu perawatan 3, 7, 14, 21 dan 28 hari setelah perendaman air laut, nilai hasil kuat tekan tidak begitu mempengaruhi hasil yang didapatkan. Namun seiring bertambahnya waktu perawatan maka berat benda uji semakin berkurang dan kuat tekan meningkat. 


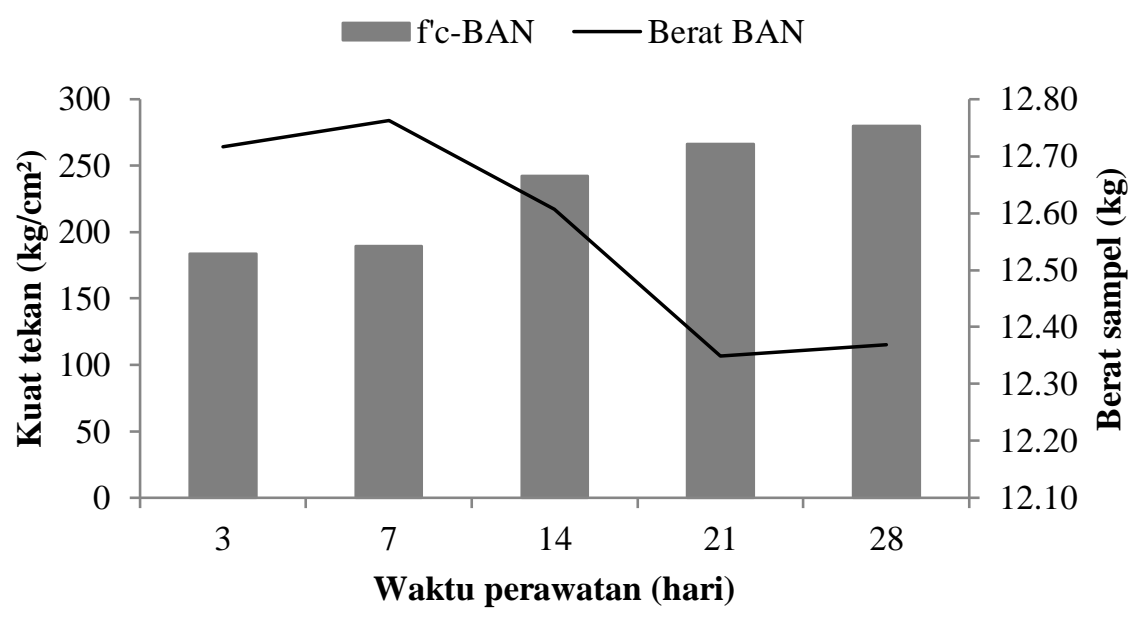

Gambar 7. Hubungan berat spesimen dan waktu rendaman terhadap kuat tekan BAN

\section{KESIMPULAN}

Dari hasil pengujian yang telah dilakukan, penelitian ini memberikan beberapa kesimpulan:

a) Pengaruh rendaman air laut tidak signifikan menurunkan kuat tekan beton BAR setelah membandingkan nilai kuat tekan beton BAN yang melampaui rencana mutu beton.

b) Belum tercapainya mutu beton rencana terhadap beton BAR karena kualitas RAK yang masih didominasi oleh mortar lama yang dapat menurunkan sifat mekanis dalam campuran.

c) Setelah perendaman air laut, berat beton BAR tidak memiliki perbedaan berarti jika dibandingkan dengan beton BAN.

\section{DAFTAR PUSTAKA}

Akshat Dimri, Jay Kr. Varshney, V. K. Verma, Sandeep Gupta, and G.B.Pant. (2015).University of Agriculture and Technology, Pantnagar, "A Review on Strength of Concrete in Seawater," International Journal of Engineering Research and, vol. V4, no. 03.

A. M. Ahmad Zaidi. (2009). Assessment of Recycled Aggregate Concrete. Modern Applied Science, vol. 3, no. 10.

H. Guo et al. (2018). Durability of Recycled Aggregate Concrete - A Review. Cement and Concrete Composites, vol. 89, pp. 251-259.

L. Sulaiman. (2018). Evaluasi Kuat Tekan Beton Recycle Agregat Dengan Campuran Air Laut Dan Prediksi Modulus Elastisitasnya. Jurnal Pena Teknik, vol. 3, no. 2 .

M. Malešev, V. Radonjanin, and S. Marinković. (2010). Recycled Concrete as Aggregate for Structural Concrete Production. Sustainability, vol. 2, no. 5, pp. 1204-1225.

N. N. Kencanawati, J. Fajrin, B. Anshari, Akmaluddin, and M. Shigeishi. (2015). Evaluation of High Grade Recycled Coarse Aggregate Concrete Quality Using Non-Destructive Testing Technique. Applied Mechanics and Materials, vol. 776, pp. 53-58. 
P. Yue, Z. Tan, and Z. Guo. (2013). Microstructure and Mechanical Properties of Recycled Aggregate Concrete in Seawater Environment. The Scientific World Journal, vol. 2013, pp. 1-7.

T. I. Abdel-Magid, O. M. Osman, O. H. Ibrahim, R. T. Mohammed, S. O. Hassan, and A. A. H. Bakkab. (2016).Influence of Seawater in Strengths of Concrete Mix Design when Used in Mixing and Curing. Key Engineering Materials, vol. 711, pp. 382-389. 
PENA TEKNIK: Jurnal Ilmiah Ilmu-Ilmu Teknik

Volume 4, Nomor 1, Maret 2019 : 1-9

Halaman ini sengaja dikosongkan 